\title{
Monocyte Function in Preterm, Term, and Adult Sheep
}

\author{
BORIS W. KRAMER, ALAN H. JOBE, AND MACHIKO IKEGAMI \\ Cincinnati Children's Hospital Medical Center, Division of Pulmonary Biology, Cincinnati, Ohio \\ 45229-3039, U.S.A.
}

\begin{abstract}
ABST
The preterm infant has functionally immature monocytes. The
effects of common clinical interventions and exposures that
might modulate inflammation were evaluated using monocytes
isolated from blood of preterm lambs [130 d gestational age
(GA)], near-term lambs (141 d GA), and adult sheep. Endotoxin
stimulated hydrogen peroxide production by adult monocytes,
but monocytes from 130-d and 141-d GA lambs had a reduced
and delayed hydrogen peroxide production. Endotoxin did not
decrease apoptosis of monocytes from 130-d and 141-d GA
lambs but decreased apoptosis of adult monocytes. Dexametha-
sone increased the phagocytosis of bacteria and apoptotic cells
by adult monocytes by 35\% but not by monocytes from 130-d
and 141-d GA lambs. Synthetic and natural surfactants and
dipalmitoylphosphatidylcholine increased phagocytosis of apo-
ptotic cells by monocytes from preterm, term, and adult sheep.
\end{abstract}
Monocytes from preterm and term lambs differ from adult monocytes in tests of both the initiation and the resolution of inflammation. The reduced phagocytosis of apoptotic cells by monocytes from the preterm may contribute to prolonged inflammation in diseases such as bronchopulmonary dysplasia.

(Pediatr Res 54: 52-57, 2003)
BPD, bronchopulmonary dysplasia
RDS, respiratory distress syndrome
SP, surfactant protein
GA, gestational age
FITC, fluorescin isothiocyanate
DPPC, dipalmitoylphosphatidylcholine
DMEM, Dulbecco's modified Eagle medium

Multiple immune defects have been described for monocytes from preterm and term newborn infants and animals (1-3). Monocytes from newborns have a reduced oxidative burst after phagocytosis of bacteria, and the second messenger responses to exogenous stimuli are different from the responses measured in adult cells $(3,4)$. Few monocytes have differentiated to macrophages in the preterm fetus, resulting in altered acute responses to inflammation and depressed immune responses (5). The normal fetus is in an environment that is normally protected from inflammation and the need to mount immune responses. Immature monocyte function may alter injury responses of fetal and newborn organs when the fetus or preterm newborn is challenged to mount an inflammatory response (5). As an example, the lung is where the preterm fetus often first encounters inflammation. Chronic indolent chorioamnionitis is frequently associated with preterm labor and increased cytokine and inflammatory cells in the lungs at birth (6-8). Chorioamnionitis and the subsequent inflammation induced by

Received October 3, 2001; accepted February 18, 2003.

Correspondence: Machiko Ikegami, M.D., Ph.D., Professor of Pediatrics, Cincinnati Children's Hospital Medical Center, Division of Pulmonary Biology, 3333 Burnet Avenue, Cincinnati, OH 45229-3039; e-mail: machiko.ikegami@cchmc.org

Supported by National Institutes of Health Grant HD 12714.

DOI: 10.1203/01.PDR.0000066621.11877.33 mechanical ventilation, oxygen, and nosocomial infection promote a persistent inflammatory response that often leads to the chronic lung disease called bronchopulmonary dysplasia (BPD) $(9,10)$.

Bone marrow-derived monocytes enter the fetal lung from the circulation in the last trimester of the pregnancy and are probably the major population of innate immune cells in the fetal lung because the majority of monocytes do not differentiate into macrophages until after term birth (11-14). Although the total number of monocyte-derived cells in the fetal lungs are not known, very few monocytes or macrophages can be recovered by alveolar lavage. Therefore, as a model system for in vitro testing, we used blood monocytes from preterm, near-term, and adult sheep to characterize monocyte responses to clinically relevant stimuli that occur in preterm infants who develop BPD. Because nosocomial infection is a risk factor for BPD (15), monocyte responses to endotoxin and phagocytosis of bacteria were evaluated. Phagocytosis of apoptotic cells was tested as a functional assay for the resolution of inflammation, because apoptotic cells that are not phagocytosed become necrotic and proinflammatory $(16,17)$. Dexamethasone and surfactant have anti-inflammatory properties that might modulate monocyte function $(18,19)$. Therefore, we evaluated the 
effects of dexamethasone and surfactant on phagocytosis of apoptotic cells.

\section{METHODS}

Cell isolation from alveolar lavage fluid. The protocols were approved by the animal use committee of the Cincinnati Children's Hospital Research Foundation. Cells were isolated from fetuses or newborn lambs from the mating of Suffolk sheep with Dorset rams. The preterm [110 d gestational age (GA), $125 \mathrm{~d}$ GA, 130d GA] and near-term (141 d GA) lambs were delivered by cesarean section. Term newborn lambs delivered spontaneously at a gestational age of $146 \pm 1 \mathrm{~d}$ and were studied at $3 \mathrm{~d}$ of age. The adult sheep were approximately $2 \mathrm{y}$ of age. Each age group consisted of four animals. For estimating macrophage numbers, left and right lungs were weighed and the left lungs were lavaged five times with $4^{\circ} \mathrm{C}$ saline and all lavages were pooled (20). Alveolar lavage fluid was centrifuged at $500 \times g$ for $10 \mathrm{~min}$, and the pellet was resuspended in PBS. Total cells were stained with trypan blue and counted. Differential cell counts were performed on cytospin preparations after staining with Diff-Quick (Scientific Products, McGaw Park, IN, U.S.A.).

Alveolar monocytes were distinguished from macrophages by measuring autofluorescence with an argon laser emitting at $430 \mathrm{~nm}$ using a FACS caliber flow cytometer (Becton Dickinson, Mountain View, CA, U.S.A.) (21). Autofluorescence measured at $530 \mathrm{~nm}$ was high in macrophages but low in monocytes (21). We used alveolar macrophages and bloodderived monocytes from adult ewes to establish a gate and analyze the alveolar cells from preterm lambs.

Monocyte and thymocyte isolation. Monocytes were the predominant cell population in preterm and term newborn lungs. Because sufficient numbers of cells for study could not be collected from alveolar washes, we isolated monocytes from cord blood or peripheral blood. Cord blood was collected from the umbilical arteries from animals at $130 \mathrm{~d}$ GA and $141 \mathrm{~d}$ GA after cesarean section. Blood from adult sheep was obtained by phlebotomy. The blood was diluted with PBS and layered onto a Percoll gradient (Amersham Pharmacia Biotech, Piscataway, NJ, U.S.A.) (22). After centrifugation for $40 \mathrm{~min}$ at $400 \times g$ at $20^{\circ} \mathrm{C}$, the mononuclear cells were recovered, washed twice with PBS at $4^{\circ} \mathrm{C}$, centrifuged for $5 \mathrm{~min}$ at $400 \times g$ at $4^{\circ} \mathrm{C}$, and resuspended in culture media [Dulbecco's modified Eagle medium (DMEM)] supplemented with $10 \%$ heat-inactivated sheep serum (Sigma Chemical Co., St. Louis, MO, U.S.A.). Cells were counted with trypan blue used to evaluate viability and plated in culture dishes. After incubation at $37^{\circ} \mathrm{C}$ for $2 \mathrm{~h}$, nonadherent cells were removed and plates were washed twice with PBS. For estimating the monocyte number, the cells were scraped from the culture dish and differential cell counts were performed after staining with Diff-Quick. The adherent cell population was $91 \pm 2 \%$ monocytes for all age groups. Thymic tissue was dissociated with a metal mesh and filtered through a cell strainer (nylon, $70 \mu \mathrm{m}$; Becton Dickinson Labware, Franklin Lakes, NJ, U.S.A.) (23). Single thymocytes were cultured as described above.
Reagents. Endotoxin from Escherichia coli, serotype O55:B5 (Sigma Chemical Co.), was resuspended in saline and filtered through a $0.45-\mu \mathrm{m}$ filter. A concentration of $100 \mathrm{ng} / \mathrm{mL}$ yielded a robust response in alveolar macrophages. Dexamethasone (Sigma Chemical Co.) was solubilized in ethanol for a stock solution of $1 \mathrm{mmol}$. Dexamethasone was tested in cell culture at concentrations from $10^{-6}$ to $10^{-9} \mathrm{~mol}$, which stimulated surfactant protein synthesis in vitro (24). Dipalmitoylphosphatidylcholine (DPPC; Sigma Chemical Co.) was resuspended in saline with glass beads (25). Surfactant (Venticute; Byk Gulden, Konstanz, Germany) contains 2\% recombinant human SP-C in DPPC and palmitoyloleoylphosphatidylglycerol in at a 70:30 (wt/wt) ratio and 5\% palmitic acid (26). This surfactant was very effective when tested in preterm lambs and in lung injury models $(27,28)$. Natural sheep surfactant containing SP-A, SP-B, and SP-C was recovered from alveolar lavages of adult sheep by centrifugation (29). Lipid extracted surfactant containing SP-B and SP-C but not SP-A was made by extraction of natural sheep surfactant with chloroform-methanol (2:1). Extracts were dried by rotary evaporation and resuspended in $0.9 \% \mathrm{NaCl}$ using glass beads (25). All surfactant and DPPC preparations were used at final concentrations of $100 \mu \mathrm{g} / \mathrm{mL}$ phospholipids based on previous studies of surfactant catabolism by alveolar macrophages in vitro (30). All surfactant preparations tested negative for endotoxin contamination with the Limulus amebocyte lysate assay (Sigma Chemical Co.).

Hydrogen peroxide production. Hydrogen peroxide was measured for $1 \times 10^{6}$ monocytes using an assay based on the oxidation of ferrous iron $\left(\mathrm{Fe}^{2+}\right)$ to ferric iron $\left(\mathrm{Fe}^{3+}\right)$ by hydrogen peroxide under acidic conditions (Bioxytech $\mathrm{H}_{2} \mathrm{O}_{2}-$ 560 assay, OXIS International, Portland, OR, U.S.A.). Control samples kept under identical incubation conditions were evaluated in all experiments (31).

Apoptotic cells and phagocytosis of apoptotic cells. Monocytes isolated as described were separated into aliquots containing the same cell numbers $\left(2 \times 10^{6} / \mathrm{mL}\right)$ for culture in sixwell plates for $24 \mathrm{~h}$. Endotoxin was added to separate wells to achieve a concentration of $100 \mathrm{ng} / \mathrm{mL} 6 \mathrm{~h}$ and $1 \mathrm{~h}$ before harvest. The control cells were cultured for $24 \mathrm{~h}$ in a separate well of the plate. The cells were scraped from the plates and centrifuged along with the medium at $400 \times g$ for $5 \mathrm{~min}$ at $4^{\circ} \mathrm{C}$. The cells were washed twice with PBS and resuspended in PBS, apoptotic cells were stained with fluorescent labeled annexin V, and necrotic cells were counterstained with proprium iodide (32). The apoptotic and necrotic cells were counted by flow cytometry and expressed as a percentage of the total cell population recovered from the plates.

Apoptosis of thymocytes was induced by $10 \mathrm{~min}$ of UV radiation followed by 3-4 h of culture (33). Phagocytosis of apoptotic thymocytes was tested by adding $2 \times 10^{6}$ apoptotic thymocytes to the adherent monocytes that had been cultured for $12 \mathrm{~h}$ (33). Surfactant preparations at final concentrations of $100 \mu \mathrm{g} / \mathrm{mL}$ phospholipids were added $15 \mathrm{~min}$ before apoptotic thymocytes were added to the cell cultures. The monocytes and apoptotic thymocytes were incubated for $6 \mathrm{~h}$ at $37^{\circ} \mathrm{C}$, washed with cold PBS containing 0.5 mM EDTA, and stained with hematoxylin and eosin. Phagocytosis was evaluated by count- 
ing 300 monocytes per well. Results were expressed as percentage of monocytes containing at least one ingested apoptotic cell.

Phagocytosis of E. coli. Monocytes were incubated with FITC-labeled E. coli (Sigma Chemical Co.) in the absence or presence of dexamethasone for $4 \mathrm{~h}$. Monocytes were resuspended, washed three times with PBS, and divided into two equal aliquots. The total bound and ingested bacteria were measured by flow cytometry. Trypan blue $(1.25 \mathrm{mg} / \mathrm{mL})$ was added to the second aliquot to measure ingested bacteria only. Trypan blue effectively quenches fluorescence of FITC labeled $E$. coli that are surface-bound but not ingested (34).

Data analysis. Results are given as means \pm SEM. Comparisons between treated groups and untreated controls were by ANOVA with Student-Newman-Keuls tests used for post hoc analyses. Significance was accepted at $p<0.05$.

\section{RESULTS}

Numbers of alveolar monocytes and macrophages. The numbers of alveolar macrophages and monocytes identified by autofluorescence were lower in preterm and term animals than in adult animals (Fig. 1). Alveolar macrophages and monocytes increased 4-fold between $141 \mathrm{~d}$ GA and $3 \mathrm{~d}$ of age after spontaneous birth. Monocytes were the predominant cell population in the preterm and term newborn lung. In the adult lung, alveolar cells were predominantly macrophages with cell numbers almost 4-fold higher per kilogram of body weight than in 3-d-old lambs.
Monocyte responses to endotoxin. Hydrogen peroxide production by monocytes from 130-d GA lambs did not increase significantly until $24 \mathrm{~h}$ after endotoxin exposure (Fig. $2 A$ ). The hydrogen peroxide was increased for monocytes from 141-d GA lambs by $6 \mathrm{~h}$. In contrast, endotoxin induced a large increase in hydrogen peroxide production by monocytes from adult sheep at $1 \mathrm{~h}$. Production of hydrogen peroxide by monocytes from 130-d and 141-d GA lambs was reduced and delayed relative to the adult monocytes.

The percentage of cells that were apoptotic after $24 \mathrm{~h}$ in culture were similar for monocytes from 130-d GA and 141-d GA lambs and adult animals without endotoxin exposure (Fig. $2 B$ ). The percentage of adult monocytes that were apoptotic were reduced after incubation with endotoxin for $1 \mathrm{~h}$ and $6 \mathrm{~h}$. This decreased apoptosis was not significant in monocytes from animals at $130 \mathrm{~d}$ GA and $141 \mathrm{~d} \mathrm{GA}$, although there was a trend toward decreased apoptosis for monocytes from the 141-d GA lambs. Total number of cells recovered after $24 \mathrm{~h}$ of culture and the percentage of necrotic cells did not change.

Dexamethasone effects on phagocytosis. Fluorescentlabeled $E$. coli were added to the cultured monocytes containing different concentrations of dexamethasone (Fig. $3 A$ ). In the absence of dexamethasone, there was no difference in the phagocytosis of fluorescent-labeled bacteria for monocytes from all age groups. Dexamethasone increased the phagocytosis of bacteria in monocytes from adult animals by $35 \%$ and did not increase phagocytosis in monocytes from 130-d and 141-d GA lambs.

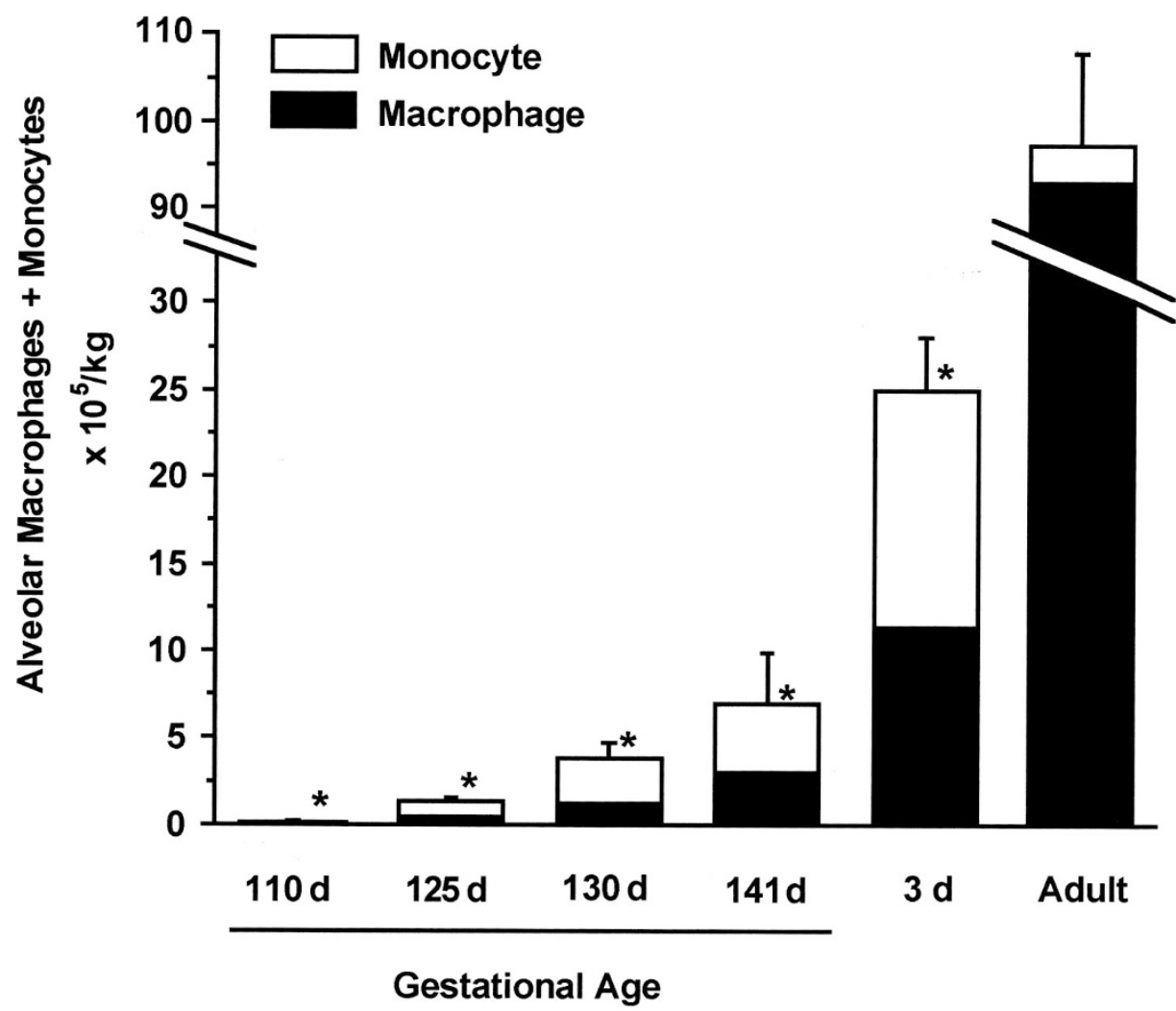

Figure 1. The numbers of alveolar macrophages and monocytes per kilogram body weight were measured in lambs at the indicated gestational ages and in 3-d-old newborn and adult sheep. Monocytes were distinguished from macrophages by autofluorescence. The number of alveolar macrophages and monocytes were lower in preterm and term animals than in newborn and adult animals. ${ }^{p} p<0.05$ versus adult 

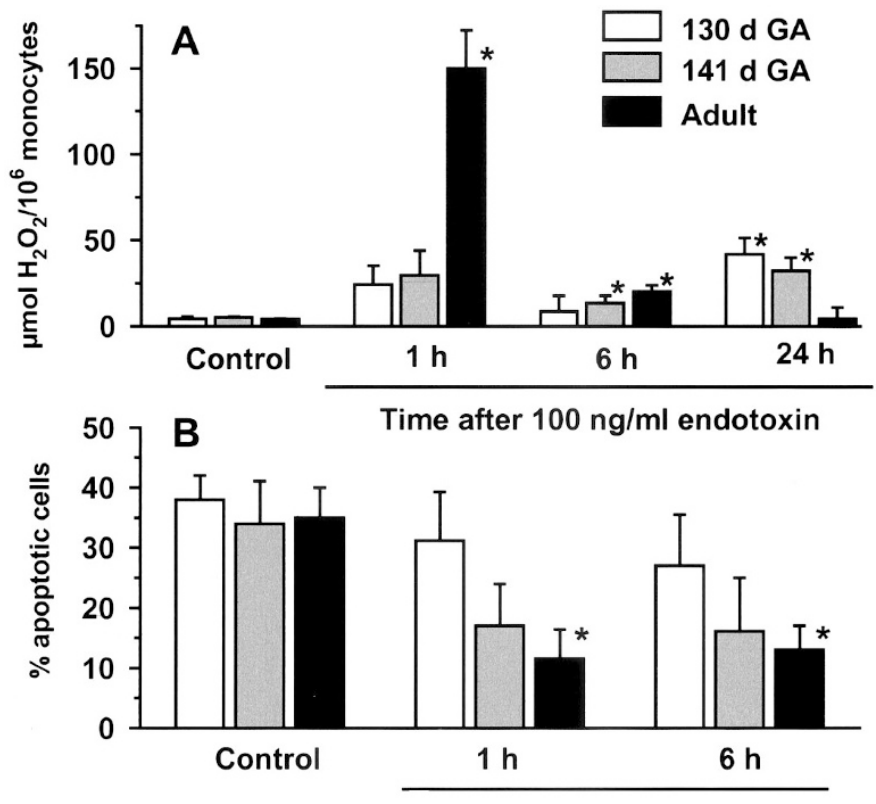

Time after $100 \mathrm{ng} / \mathrm{ml}$ endotoxin

Figure 2. Hydrogen peroxide $\left(\mathrm{H}_{2} \mathrm{O}_{2}\right)$ production and percentage of apoptotic cells after stimulation of monocytes with endotoxin. $A$, Hydrogen peroxide was measured in aliquots of $1 \times 10^{6}$ monocytes after stimulation with $100 \mathrm{ng} / \mathrm{mL}$ endotoxin. Monocytes from lambs at $130 \mathrm{~d}$ GA and $141 \mathrm{~d}$ GA produced less hydrogen peroxide and at later times than did monocytes from adult sheep. $B$, The percentage of apoptotic cells was determined as percentage of total cells recovered from plates after $24 \mathrm{~h}$ of culture and after exposure to endotoxin for $1 \mathrm{~h}$ or $6 \mathrm{~h}$. The percentage of apoptotic cells in monocytes from adult animals decreased after stimulation with endotoxin. ${ }^{*} p<0.05$ versus control

Monocytes were incubated with apoptotic thymocytes as a model of T lymphocytes for the delayed hypersensitivity reaction. The phagocytosis of apoptotic thymocytes by monocytes from 130-d GA and 141-d GA lambs was reduced relative to monocytes from adult sheep (Fig. $3 B$ ). Incubation with dexamethasone did not increase the phagocytosis of apoptotic thymocytes by monocytes from lambs at $130 \mathrm{~d}$ GA and $141 \mathrm{~d}$ GA. Dexamethasone increased phagocytosis of apoptotic thymocytes by adult monocytes.

Surfactant effects on phagocytosis of apoptotic cells. Evaluations of phagocytosis were done in the presence of natural sheep surfactant, lipid-extracted sheep surfactant, recombinant human SP-C surfactant, and DPPC. All surfactants and DPPC increased the phagocytosis of apoptotic thymocytes in the monocyte cultures (Fig. 4). There were qualitative differences in the phagocytosis with the different surfactants, probably as a result of the surfactant proteins. Natural surfactant containing SP-A, SP-B, and SP-C increased the phagocytosis more than DPPC alone in monocytes from adults and from lambs at $130 \mathrm{~d}$ GA and $141 \mathrm{~d}$ GA. Lipid-extracted surfactant containing SP-B and SP-C also increased the phagocytosis by monocytes from adult animals more than DPPC alone.

\section{DISCUSSION}

Alveolar macrophages initiate the innate inflammatory response and clear inflammation (17). We evaluated both functions in a model system using peripheral monocytes from

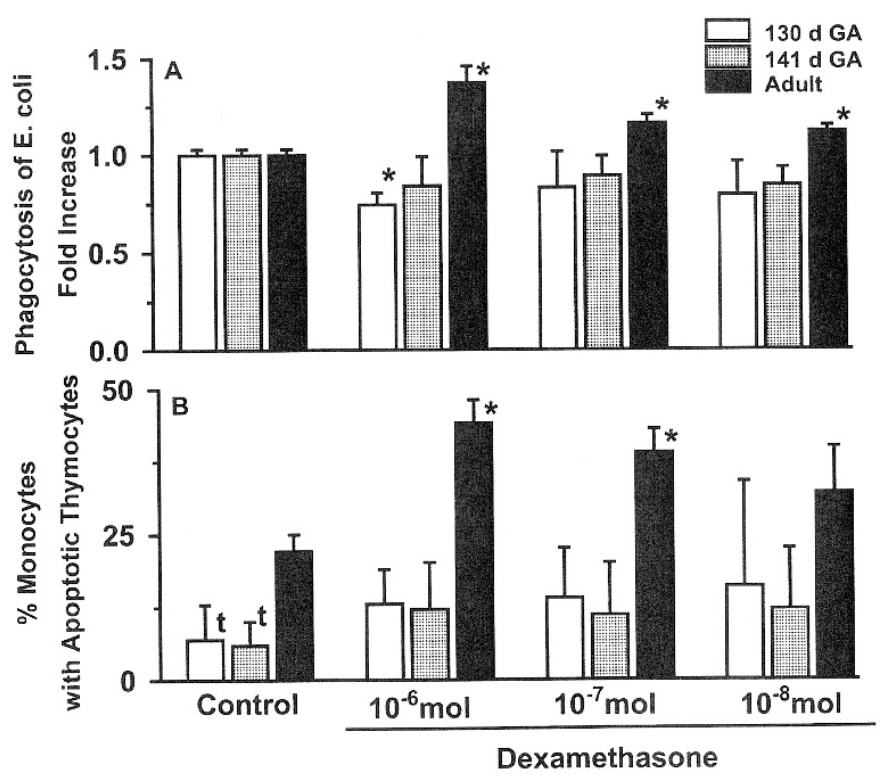

Figure 3. Effect of dexamethasone on phagocytosis. A, Monocytes were incubated with FITC-labeled E. coli in the presence or absence of dexamethasone. Phagocytosis of fluorescent-labeled bacteria is shown relative to the control value of 1 . Dexamethasone increased the phagocytosis of fluorescentlabeled bacteria in monocytes from adult animals but not in monocytes from 130 -d and 141-d GA animals ( $* p<0.05$ versus control). $B$, Results are given as percentage of monocytes that contained at least one apoptotic thymocyte. Phagocytosis of apoptotic thymocytes was lower in monocytes from lambs at $130 \mathrm{~d} \mathrm{GA}$ and $141 \mathrm{~d}$ GA than from adult monocytes under control conditions. Incubation with dexamethasone did not increase the phagocytosis in monocytes from lambs at $130 \mathrm{~d}$ GA and $141 \mathrm{~d}$ GA but increased phagocytosis by monocytes from adult animals. ${ }^{*} p<0.05$ versus control; $\mathrm{t} p<0.05$ versus adult

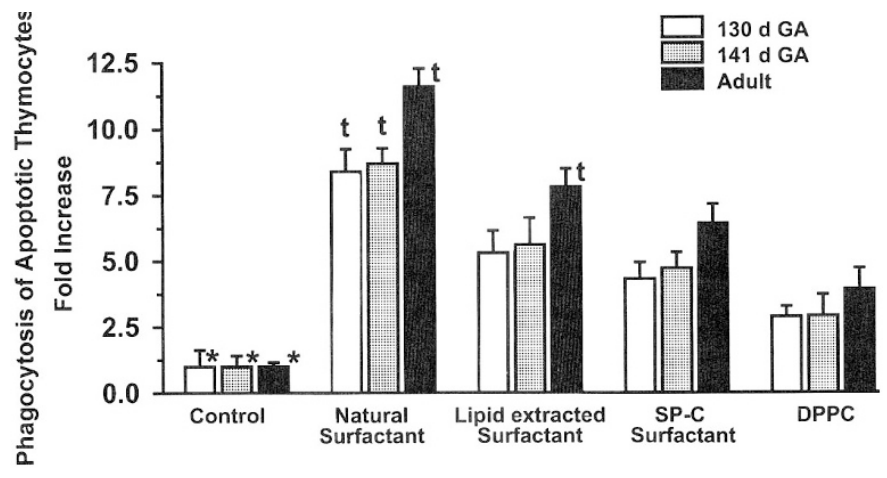

Figure 4. Effect of surfactants and DPPC on phagocytosis of apoptotic thymocytes. Phagocytosis of apoptotic cells are shown as increase over controls, which had a normalized value of 1 . The addition of different surfactant preparations and DPPC at $100 \mu \mathrm{g}$ phospholipid per milliliter of culture media increased the percentage of monocytes that phagocytosed apoptotic cells. Natural surfactant caused the largest increase. Natural surfactant increased the phagocytosis more than DPPC alone. ${ }^{*} p<0.05$ versus all other groups; $\mathrm{t} p<0.05$ versus DPPC

preterm, near-term, and adult sheep. The rationale for using monocytes from blood was that most of the cells recovered by alveolar lavage of preterm and term lambs were monocytes rather than macrophages, as has also been reported for other species $(11,12,35,36)$. A limitation to this study is the use of blood monocytes, which may differ from the monocyte pool in the fetal lung. Approximately $10 \%$ of the blood monocyte pool 
express homing receptors for the lung, which are up-regulated with infection or lung injury (13). Although pulmonary intravascular macrophages contribute to lung inflammation in adult ruminants and pigs, there are no pulmonary intravascular macrophages in newborn pigs and the number is low in term lambs (37). There is no information about pulmonary intravascular macrophage populations in preterm sheep. The differences between premature, newborn, and adult immune cells are mechanistically very complex. For example, phagocytosis of opsonized particles is normal in term human newborn neutrophils; however, the respiratory burst may be impaired (1). The second messenger responses to exogenous stimuli are different for immune cells from newborn and adult cells (4).

This study was designed to evaluate monocyte functions that might be relevant to clinical exposures and interventions for BPD. BPD develops after prolonged inflammation in the lung (38). This inflammation can be initiated prenatally by chorioamnionitis or can be initiated and sustained by postnatal treatments that have proinflammatory effects such as oxygen exposure, nosocomial infection, and mechanical ventilation $(31,39$, 40). The hydrogen peroxide responses of preterm and nearterm monocytes to endotoxin were reduced and delayed. Endotoxin exposure did not reduce the percentage of apoptotic monocytes from lambs at $130 \mathrm{~d}$ GA and $141 \mathrm{~d}$ GA. Dexamethasone increased the phagocytosis of bacteria and apoptotic thymocytes by monocytes from adult animals but not by monocytes from lambs at $130 \mathrm{~d}$ GA and $141 \mathrm{~d}$ GA. Monocytes from lambs at $130 \mathrm{~d}$ GA and $141 \mathrm{~d}$ GA have a reduced capacity to clear inflammation by phagocytosis of apoptotic inflammatory cells. However, phagocytosis of apoptotic cells was increased by surfactant and DPPC. Our results suggest that once an inflammatory response is present, the clearance of inflammation may be prolonged as a result of a defect in the phagocytosis of apoptotic cells. Apoptotic cells become necrotic if they are not phagocytosed $(16,41)$, and necrotic cells release toxic contents and proinflammatory mediators that may sustain inflammation (42).

A new finding is that surfactant increased phagocytosis by monocytes from all ages of sheep. The enhanced phagocytosis of apoptotic cells may contribute to the anti-inflammatory properties of surfactant treatment (1). The phagocytosis of apoptotic cells by alveolar macrophages was previously reported to be enhanced by SP-A (43). There was a qualitative tendency for natural surfactant to enhance more effectively the phagocytosis of apoptotic cells compared with DPPC alone. The enhancement of phagocytosis by DPPC may result from the interaction of phospholipids with the phosphatidylserine receptor (44). Phosphatidylserine is exposed in the outer membrane of cells undergoing apoptosis (32), and the phosphatidylserine receptor mediates the phagocytosis of apoptotic cells (45). The enhanced phagocytosis by surfactant may be compromised in BPD because the surfactant from baboons developing BPD is deficient in SP-A and SP-D $(46,47)$. Increased apoptosis or necrosis of monocytes was not the reason for the reduced phagocytosis of apoptotic thymocytes.

Infants with BPD have been treated with dexamethasone to reduce inflammation and the duration of mechanical ventilation (48). We found that dexamethasone did not reduce the phago- cytosis of bacteria by monocytes from lambs at $130 \mathrm{~d}$ GA and $141 \mathrm{~d}$ GA. In contrast, dexamethasone increased the phagocytosis of both bacteria and apoptotic cells by adult monocytes, a response similar to that described previously for alveolar macrophages from newborn rat lungs (49). The effect of dexamethasone on phagocytosis by monocytes from preterm and nearterm lambs will not augment the immature immune system. The significance of this effect is unknown for humans who are being treated postnatally with dexamethasone for BPD.

We found that monocytes from preterm lambs are different from monocytes from adult sheep in both the initiation and the resolution of inflammation. There was no difference between the cells from 131- and 141-d lambs, indicating that the maturation of function is a postterm event. Inflammatory cells persisted in the lungs of preterm fetal lambs for weeks after a single exposure to intra-amniotic endotoxin (39). The reduced phagocytosis in preterm monocytes may contribute to the persistent lung inflammation after chorioamnionitis. Dexamethasone may not increase the clearance of bacteria or apoptotic cells in preterm lungs. The low amounts of surfactant and SP-A in preterm lungs and lungs developing BPD may also adversely affect phagocytosis $(46,47)$.

Acknowledgments. Byk Gulden, Konstanz, Germany, provided Venticute.

\section{REFERENCES}

1. Speer CP 2001 New insights into the pathogenesis of pulmonary inflammation in preterm infants. Biol Neonate 79:205-209

2. Tomai MA, Fitzgerald TJ, Froberg MK 1992 Macrophage and lymphocyte functions are down-regulated in newborn rabbits. J Leukoc Biol 51:151-156

3. Weiss RA, Chanana AD, Joel DD 1986 Postnatal maturation of pulmonary antimicrobial defense mechanisms in conventional and germ-free lambs. Pediatr Res 20:496-504

4. Marshall-Clarke S, Reen D, Tasker L, Hassan J 2000 Neonatal immunity: how well has it grown up? Immunol Today 21:35-41

5. Lee PT, Holt PG, McWilliam AS 2000 Role of alveolar macrophages in innate immunity in neonates: evidence for selective lipopolysaccharide binding protein production by rat neonatal alveolar macrophages. Am J Respir Cell Mol Biol 23:652-661

6. Goldenberg RL, Hauth JC, Andrews WW 2000 Intrauterine infection and preterm delivery. N Engl J Med 342:1500-1507

7. Schmidt B, Cao L, Mackensen-Haen S, Kendziorra H, Klingel K, Speer CP 2001 Chorioamnionitis and inflammation of the fetal lung. Am J Obstet Gynecol 185:173177

8. Yoon BH, Romero R, Moon JB, Shim SS, Kim M, Kim G, Jun JK 2001 Clinical significance of intra-amniotic inflammation in patients with preterm labor and intact membranes. Am J Obstet Gynecol 185:1130-1136

9. Jobe AH 1999 The New BPD: An arrest of lung development. Pediatr Res 46:641643

10. Jobe A, Bancalari E 2001 Bronchopulmonary dysplasia. Am J Respir Crit Care Med $163: 1723-1729$

11. Zeligs BJ, Nerurkar LS, Bellanti JA, Zeligs JD 1977 Maturation of the rabbit alveolar macrophage during animal development. I. Perinatal influx into alveoli and ultrastructural differentiation. Pediatr Res 11:197-208

12. Jacobs RF, Wilson CB, Palmer S, Springmeyer SC, Henderson WR, Glover DM, Kessler Jr DL, Murphy JH, Hughes JP, van Belle G, Chi EY, Hodson WA 1985 Factors related to the appearance of alveolar macrophages in the developing lung. Am Rev Respir Dis 131:548-553

13. Sherman MP, Truog WE 1999 The role of pulmonary macrophages in chronic lung disease of early infancy. In: Bland RD, Coalson JJ (eds) Chronic Lung Disease in Early Infancy. Marcel Dekker, New York, pp 813-839

14. Radzun HJ, Parwaresch MR, Kreipe H 1983 Monocytic origin of human alveolar macrophages. J Histochem Cytochem 31:318-324

15. Rojas MA, Gonzalez A, Bancalari E, Claure N, Poole C, Silva-Neto G 1995 Changing trends in the epidemiology and pathogenesis of neonatal chronic lung disease. J Pediatr 126:605-610

16. Grigg JM, Savill JS, Sarraf C, Haslett C, Silverman M 1991 Neutrophil apoptosis and clearance from neonatal lungs. Lancet 338:720-722

17. Cox G, Crossley J, Xing Z 1995 Macrophage engulfment of apoptotic neutrophils contributes to the resolution of acute pulmonary inflammation in vivo. Am J Respir Cell Mol Biol 12:232-237 
18. Wright JR 1997 Immunomodulatory functions of surfactant. Physiol Rev 77:931-962 19. Sinkin RA, Dweck HS, Horgan MJ, Gallaher KJ, Cox C, Maniscalco WM, Chess PR, D'Angio CT, Guillet R, Kendig JW, Ryan RM, Phelps DL 2000 Early dexamethasone-attempting to prevent chronic lung disease. Pediatrics 105:542-548

20. Wada K, Jobe AH, Ikegami M 1997 Tidal volume effects on surfactant treatmen responses with the initiation of ventilation in preterm lambs. J Appl Physiol 83:10541061

21. Skold CM, Eklund A, Hallden G, Hed J 1990 Different cell surface and phagocytic properties in mononuclear phagocytes from blood and alveoli. A comparative study of blood monocytes and alveolar macrophages from human nonsmokers using flow cytofluorometry. APMIS 98:415-422

22. Kanof ME, Smith PD, Zola H 1996 Separation of peripheral blood mononuclear cells In: Coligan JE, Kruisbeek AM, Margulies DH, Shevach EM, Strober W (eds) Current Protocols in Immunology. Wiley, New York, pp 711-717

23. Kruisbeek AM 1996 Isolation and fractionation of mononuclear cell populations. In: Coligan JE, Kruisbeek AM, Margulies DH, Shevach EM, Strober W (eds) Current Protocols in Immunology. Wiley, New York, pp 311-315

24. Shannon JM, Pan T, Nielsen LD, Edeen KE, Mason RJ 2001 Lung fibroblasts improve differentiation of rat type II cells in primary culture. Am J Respir Cell Mol Biol 24:235-244

25. Ikegami M, Korfhagen TR, Bruno MD, Whitsett JA, Jobe AH 1997 Surfactan metabolism in surfactant protein A-deficient mice. Am J Physiol 272:L479-L485

26. Davis AJ, Jobe AH, Häfner D, Ikegami M 1998 Lung function in premature lambs and rabbits treated with a recombinant SP-C surfactant. Am J Respir Crit Care Med 157:553-559

27. Ikegami M, Jobe A 2002 Injury responses to different surfactants in ventilated premature lamb lungs. Pediatr Res 51:689-695

28. Lewis J, McCaig L, Hafner D, Spragg R, Veldhuizen R, Kerr C 1999 Dosing and delivery of a recombinant surfactant in lung-injured adult sheep. Am J Respir Crit Care Med 159:741-747

29. Ikegami M, Jobe A, Jacobs H, Jones SJ 1981 Sequential treatments of premature lambs with an artificial surfactant and natural surfactant. J Clin Invest 68:491-496

30. Yoshida M, Ikegami M, Reed JA, Chroneos ZC, Whitsett JA 2001 GM-CSF regulates protein and lipid catabolism by alveolar macrophages Am J Physiol 280:L379-L386

31. Kramer BW, Moss TJ, Willet K, Newnham J, Sly P, Kallapur SG, Ikegami M, Jobe A 2001 Dose and time response after intra-amniotic endotoxin in preterm lambs. Am J Respir Crit Care Med 164:982-988

32. Vermes I, Haanen C, Steffens-Nakken H, Reutelingsperger C 1995 A novel assay fo apoptosis. Flow cytometric detection of phosphatidylserine expression on early apoptotic cells using fluorescein labelled Annexin V. J Immunol Methods 184:39-51

33. Hu B, Sonstein J, Christensen PJ, Punturieri A, Curtis JL 2000 Deficient in vitro and in vivo phagocytosis of apoptotic $\mathrm{T}$ cells by resident murine alveolar macrophages. J Immunol 165:2124-2133
34. Hed J, Hallden G, Johansson SG, Larsson P 1989 Quantitative rather than qualitative differences between monocytes with respect to $\operatorname{IgE~Fc~receptor~expression~as~studied~}$ by flow cytofluorometry. Int Arch Allergy Appl Immunol 88:408-411

35. Sherman MP, D'Ambola JB, Aeberhard EE, Barrett CT 1988 Surfactant therapy of newborn rabbits impairs lung macrophage bactericidal activity. J Appl Physiol 65:137-145

36. Coalson JJ, Winter VT, Siler-Khodr T, Yoder BA 1999 Neonatal chronic lung disease in extremely immature baboons. Am J Respir Crit Care Med 160:1333-1346

37. Longworth KE, Albertine KH, Staub NC 1996 Ultrastructural quantification of pulmonary intravascular macrophages in newborn and 2-week-old lambs. Anat Rec 246:238-244

38. Groneck P, Speer CP 1995 Inflammatory mediators and bronchopulmonary dysplasia. Arch Dis Child 73:F1-F3

39. Kallapur SG, Willet KE, Jobe AH, Ikegami M, Bachurski C 2001 Intra-amniotic endotoxin: chorioamnionitis precedes lung maturation in preterm lambs. Am J Physiol 280:L527-L536

40. Bancalari E 2001 Changes in the pathogenesis and prevention of chronic lung disease of prematurity. Am J Perinatol 18:1-9

41. Savill J, Fadok V, Henson P, Haslett C 1993 Phagocyte recognition of cells undergoing apoptosis. Immunol Today 14:131-136

42. Mann CL, Cidloski JA 1999 Signaling cascades of apoptosis. In: Winkler JD (eds) Apoptosis and Inflammation. Birkhäuser, Basel, pp 7-18

43. Schagat TL, Wofford JA, Wright JR 2001 Surfactant protein A enhances alveolar macrophage phagocytosis of apoptotic neutrophils. J Immunol 166:2727-2733

44. Huynh M-L, Fadok VA, Henson PM 2001 TGFb1 secretion and resolution of pulmonary inflammation are increased after phosphatidylserine dependent in vivo ingestion of apoptotic cells. Am J Respir Crit Care Med 163:A246

45. Fadok VA, Bratton DL, Rose DM, Pearson A, Ezekewitz RA, Henson PM 2000 A receptor for phosphatidylserine-specific clearance of apoptotic cells. Nature 405:85-90

46. Hallman M, Merritt TA, Akino T, Bry K 1991 Surfactant protein-A, phosphatidylcholine, and surfactant inhibitors in epithelial lining fluid: correlation with surface activity, severity of respiratory distress syndrome, and outcome in small premature infants. Am Rev Respir Dis 144:1376-1384

47. Awasthi S, Coalson JJ, Crouch E, Yang F, King RJ 1999 Surfactant proteins A and $\mathrm{D}$ in premature baboons with chronic lung injury. Evidence for an inhibition of secretion. Am J Respir Crit Care Med 160:942-949

48. Bancalari E 1998 Corticosteroids and neonatal chronic lung disease. Eur J Pediatr 157:S31-S37

49. Lortie C, King GM, Adamson IY 1990 Effects of dexamethasone on macrophages in fetal and neonatal rat lung. Pediatr Pulmonol 8:138-144 